\title{
25 Research Square \\ Human Health Risks Surveillance of Polychlorinated Biphenyls in Bovine Milk from Alluvial Plain of Punjab, Pakistan
}

\section{Saman Sana}

University of the Punjab Quaid-i-Azam Campus

Abdul Qadir ( $\sim$ aqadir.cees@pu.edu.pk)

University of the Punjab https://orcid.org/0000-0002-4873-237X

Neil P Evans

University of Glasgow Faculty of Veterinary Medicine

Mehvish Mumtaz

University of the Punjab Quaid-i-Azam Campus

Ambreena Javaid

Kinnaird College for Women

Amjad Khan

University of Veterinary and Animal Sciences

Saif-ur-Rehman Kashif

University of Veterinary and Animal Sciences

Habib ur Rehman

University of Veterinary and Animal Sciences

\section{Research Article}

Keywords: Cattle farming, Dioxin-like PCBs, Indicator PCBs, PCBs accumulation, Dairy Products, Human health risk

Posted Date: November 2nd, 2021

DOI: https://doi.org/10.21203/rs.3.rs-953903/v1

License: (c) (i) This work is licensed under a Creative Commons Attribution 4.0 International License.

Read Full License 


\section{Abstract}

Punjab is the leading province of Pakistan in the production of bovine milk and its consumption. Rapid industrialization, high energy demand and production of waste have increased the risk of PCB toxicity in the environment. This research work was designed to assess human dietary exposure of polychlorinated biphenyls ( $\sum$ PCBs 17 congeners) through ingestion of buffalo and cow's milk from eight main districts of Punjab, Pakistan. The average concentration of $\sum$ DL-PCBs in buffalo and cow milk samples were analyzed (8.74 $\mathrm{ng} \mathrm{g}^{-1}$ and $14.60 \mathrm{ng} \mathrm{g}^{-1}$ ) and $\sum$ I-PCBs (11.54 $\mathrm{ng} \mathrm{g}^{-1}$ and $\left.18.68 \mathrm{ng} \mathrm{g}^{-1}\right)$ respectively. The PCB-156 was predominantly high congener found in both buffalo $\left(2.84 \mathrm{ng} \mathrm{g}^{-1}\right)$ and cow milk (2.86 $\mathrm{ng} \mathrm{g}$ $\left.{ }^{1}\right)$. It was found that the highest PCBs in bovine milk samples were observed in close vicinities of urban and industrial areas. The estimated daily consumptions of DL-PCBs and I-PCBs, from buffalo and cow milk, were below the acceptable daily intake for both adults and children. Moreover, Hazard Quotients $(\mathrm{HQ})$ of $\sum \mathrm{PCBs} 17$ congeners value were less than 1.0 in adults and greater in the case of children reflecting the high chances of cancer risk. Furthermore, comprehensive monitoring for childhood cancer is recommended to establish the relationship in future studies.

\section{Introduction}

Persistent organic pollutants (POPs) are posing the potential health impacts concerns and persistence within the environment owing to their long-range transportation, bioaccumulation, and carcinogenic properties (Meng et al. 2017, Sohail et al. 2018, Weber et al. 2019). Polychlorinated Biphenyls (PCBs), were discussed in Stockholm Convention on POPs, 2001 because of their adverse effects on the health of humans and environment (WHO 2010). PCBs generally produced for their outstanding electric insulation properties and were once extensively used in transformers and capacitors as coolant fluids (Hulin et al. 2020, Kabir et al. 2015). Despite a drastic decline in their manufacture since the 1960 s, due to their accessibility, low cost, and adaptability, PCBs are still used for cooling and insulation along with transformer oil, in many developing countries like Pakistan (Eqani et al. 2012, Mahmood et al. 2014a). Furthermore, their use in cable insulation, as plasticizers, pigments, paints, and hydraulic equipment (EPA 2021) means that there remains a worldwide demand for 4000 MT of PCB per year (Eqani et al. 2012). Along with the production of new PCBs, the environmental load of PCBs is being enhanced by various thermal and industrial processes including incineration, metallurgy and cement production, uncontrolled burning of waste, inappropriate dumping of e-waste, leakage of oil from transformers, open electronics repair workshops, incineration sites, polluted goods, municipal and industrial wastewater disposal (Gong et al. 2017). (Breivik K et al. 2002, EPA 2004, Eqani et al. 2013, Mahmood et al. 2014a). Despite safety concerns and restrictions in their production, PCBs are still ubiquitous within the environment and are detectable in various matrices in many countries so human exposure remains possible (Bányiová et al. 2017, Lind et al. 2019).

The 209 PCB congeners are divided into two broad groups: "dioxin-like PCBs (DL-PCBs)" and "indicator PCBs (I-PCBs)" which are often used as markers in pollution studies (Ahmadkhaniha et al. 2017, Rosinska \&Karwowska 2017). These congeners of DL-PCBs and I-PCBs are detected in higher 
concentrations in various environmental matrices including food, human fluids, and tissues (Lyon 2016), indicating their potential for bioaccumulation and increasing their risk to human health. Concern about environmental levels of PCBs arises as PCBs are categorized as carcinogenic to human beings (Group 1) (IARC 2012) and it has been estimated that high-fat foods, like dairy products especially milk (Costabeber et al. 2018, Roveda et al. 2006), eggs and animal-based products, contribute $90 \%$ of human PCB exposure (EFSA 2018, Fadaei et al. 2015, FAO/WHO 2018, Malisch \&Kotz 2014), particularly for infants (Sarode et al. 2016) and children (Lamarche et al. 2016, Larsson et al. 2015). In 2018, 838 million tons of milk was produced globally with a significant contribution coming from India and Pakistan. Currently, Pakistan is the fourth leading milk producer globally (Ishaq et al. 2018, Perisic et al. 2015, Sana et al. 2021) and it's expected that in the coming decade, Pakistan's milk production will continue to increase (FAO 2019). PCBs levels in milk have been published for many countries including, France (Hulin et al. 2020), Slovakia (Toman et al. 2020), Italy (Bertocchi et al. 2015, Chirollo et al. 2018, Esposito et al. 2010, Tremolada et al. 2014), Brazil (Costabeber et al. 2018, Heck et al. 2007), Iran (Ahmadkhaniha et al. 2017), California (Chen et al. 2017), Mexico (Pérez et al. 2012), Netherland (Baars et al. 2004), Siberia (Mamontova et al. 2007), Belgium (Focant et al. 2003), Germany (Kerst et al. 2004), Chile (PizarroAranguiz et al. 2015), South Korea (Son et al. 2012), India (V.Vanitha et al. 2010) and the United kingdom (Sewart \&Jones 1996). While reports on PCBs concentrations in various environmental matrices including soil, air, water, and sediments (Ali et al. 2015, Baqar et al. 2017, Eqani et al. 2015, Mahmood et al. 2014a, Syed et al. 2014, Syed et al. 2013), and some elements of the food chain (Mahmood et al. 2014b, Mumtaz et al. 2016) within Pakistan had been published. Till- date, no reports are available that detail the PCB concentrations in bovine milk. Acceptable limits of PCBs in milk in Pakistan have also not been defined. The main objective of the current research was to explore the concentration levels and spatial of distribution of DL-PCBs and I-PCBs in bovine milk and evaluate health risks related to PCB consumption in milk by children and adults.

\section{Methodology \\ 2.1. Material}

All chemicals used in this study were of grade that is suitable for analysis. PCBs native standards, PCB209 and Tetra-chloro-meta-xylene (TCmX) were acquired from AccuStandard (America) and stored at $-20^{\circ} \mathrm{C}$. Ethanol, Hexane, Acetone and Di-chloro-methane (DCM) were obtained from Merck. Pure $\mathrm{N}_{2}$ was procured from a local gas filling facility. Columns required for Solid Phase Extraction (SPE), used for cleanup of samples were attained from SILICYCLE $E_{\text {Inc }}$ (SPEC-R31830B-06P, Certified SiliaPrep ${ }^{\mathrm{M}}$ C18, 500 $\mathrm{mg} / 6 \mathrm{~mL})$.

\subsection{Sampling strategy}

Eight districts of Punjab with industrial (Eqani et al. 2015) and agricultural (Ali et al. 2015) significance were selected for the collection of samples (milk) from buffaloes $(n=26)$ and cows $(n=28)$ (March to December 2018). The study area map is presented as Fig. S1 and the coordinates are given in Table S1. 
The samples were collected from randomly selected buffaloes and cows, in their native environment, as part of normal milking during either early morning or evening. Samples were placed in glass bottles of a dark color (amber), sealed, labeled, transferred to an icebox, and taken to Environmental Toxicology Laboratory at College of Earth and Environmental Sciences, University of the Punjab, Lahore where they were kept at $-20^{\circ} \mathrm{C}$ until further analysis (Deti et al. 2014, Ibigbami et al. 2019, Sajid et al. 2016). During the sample collection, a questionnaire (Table S2) was used to record the native environment, living conditions, and the demographic settings of the buffaloes and cows.

\subsection{Sample Preparation}

Extraction and the cleanup process of PCBs were conducted with minor modifications to previously published methods (Dewan et al. 2013, Sana et al. 2021). Concisely, after maintaining a room temperature of the samples, $1 \mathrm{ml}$ was taken per sample and spiking was conducted with $50 \mu \mathrm{l} \mathrm{TCMX}$ $(100 \mathrm{ppb})$. Samples were incubated overnight (at $4^{\circ} \mathrm{C}$ ) after the addition of $6 \mathrm{ml}$ of $\mathrm{n}$-hexane and $3 \mathrm{ml}$ of acetone. Samples were then sonicated (with sonicator: Model PS-20A) for 60 minutes on $3^{\circ} \mathrm{C}$ before being centrifuged (Model 800 Electronic Centrifuge) at $3500 \mathrm{rpm}$ for ten minutes. The resulting supernatant was transferred to a separate glass vial and the residual sample was extracted two times with $\mathrm{n}$-hexane and was added to the same container.

The milk extract was cleaned up by SPE with C18 silica cartridges from SILICYCLE, (Aguilera-Luiz 2011). Cartridges were primed with $n$-hexane, before application of samples and elution of PCBs $(2 \times 5 \mathrm{~mL}$ of DCM). The eluates were concentrated using pure $\mathrm{N}_{2}$ gas streaming (Sosan 2017). Further, $50 \mu \mathrm{L}$ of 100 $\mathrm{ng} \mathrm{g}^{-1}$ strength of ${ }^{13} \mathrm{C}$-PCB-209 was added to the $1 \mathrm{~mL}$ sample (final volume). The samples were filtered through a $0.22 \mu \mathrm{m}$ filter and kept in $1.5 \mathrm{~mL}$ vials (glass) till further analysis.

\subsection{Sample Analysis}

The PCB content of samples was analyzed using Gas Chromatography-Mass Spectrometer (Agilent Technologies, 5975C inert XL El/CI MSD using Triple Axis detector; 7890A GC System) tailored along with an Auto-Sampler (Agilent Technologies 7693), at Environmental Biotechnology Laboratory at University of Glasgow, United Kingdom. Selected lon Monitoring (SIM) mode was selected for the study of 17 PCBs (DL-PCBs including PCB 77, 81, 126, 169, 105, 114, 118, 156, 157, 167 and 189 and I-PCBs comprising PCB 28, 52, 101, 138, 153 and 180). A varian column with specifications (CP-Sil 8CB, $50 \mathrm{~m}, 0.25 \mathrm{~mm}$, and $0.25 \mu \mathrm{m}$ ) and injector port at $250^{\circ} \mathrm{C}$ were used. The basic temperature of the MSD (mass spectrometric detector) was $230^{\circ} \mathrm{C}$ and then lowered to $150^{\circ} \mathrm{C}$ (quadruple temperature). The succeeding arrangement was used for analyzing all samples: initial 3 minutes temperature was $150^{\circ} \mathrm{C}$ then $4^{\circ} \mathrm{C}$ per minute up to $290^{\circ} \mathrm{C}$. The isothermal process was maintained for 10 minutes.

\subsection{Quality assurance and quality control}

Distilled water was used for washing glassware then it was rinsed with DCM and dried at $450{ }^{\circ} \mathrm{C}$ for almost 6 hours before use. Standards of 1, 10,20,50, 100, 200, 500 and $1000 \mathrm{ng} \mathrm{g}^{-1}$ were used for developing calibration curves and standardization of instruments. Limit of Detection (LOD) was set at $3 x$ 
the signal to noise ratio (S/N), while Limit of Quantification (LOQ) was 10x the S/N. The table of LOD and LOQ are given as Table S5. Samples were investigated in small groups with a procedural blank run after every 10 samples. PCB concentration was lesser than the limits in all of the field, procedural and blanks of solvent. The range of the recovery for $\mathrm{TCmX}$ was $75-84 \%$. The spiked recovery was $88-151 \%$ (mean $=$ $105 \%$ ). The considered relative standard deviation of the spiked replicates was $20 \%$ (mean $=11 \%$ ). Integration of peaks and data analysis was done by software (Agilent MSD productivity Chemstation).

\subsection{DL-PCBs Toxicity Equivalence}

The toxicity profile of DL-PCBs was evaluated by assessing the toxicity equivalence (TEQs) by equation (1), where $C$ represents the concentration of DL-PCB congeners and TEF denotes toxic equivalency factor as per the World Health Organization (WHO), International Program on Chemical Safety (WHO-IPCS), 2005 (Van den Berg et al. 2006).

$T E Q=C \times T E F$

\subsection{Risk Assessment of Human Health}

Guidelines from USEPA were followed for the calculation of health risks (non-carcinogenic and carcinogenic) for adults and children (Dougherty et al. 2000, Sosan 2017). Expected Daily Intake (EDI) (ng $\mathrm{Kg}^{-1} \mathrm{~d}^{-1}$ ) of PCBs from milk consumption was calculated according to the following formula (equation 2) (Binelli \&Provini 2004).

$E D I=\frac{C R \times C}{B W}$

$\mathrm{CR}$ is the rate of milk consumption $\left(\mathrm{mL} \mathrm{d}^{-1}\right)$ (Pakistan Economic Survey 2018), C represents measured concentration ( $\mathrm{ng} \mathrm{g}^{-1}$ ) of PCBs congeners, BW is Body weight (children $=27.7 \mathrm{Kg}$ and adults $=60 \mathrm{Kg}$ ) (Adeleye 2019, Sosan 2017). The risk level posed to human beings can be represented by using all these parameters (Dougherty et al. 2000, Wang et al. 2011).

\subsubsection{Non-carcinogenic risk assessment}

To evaluate the health risks not causing cancer, a comparison was done between EDI (PCBs in milk) and Acceptable Daily Intake (ADI).

\subsubsection{Carcinogenic risk assessment}

The Hazard Ratio (HR) was found by following (Dougherty et al. 2000) equation 3 where CBC (ng Kg ${ }^{-1}$ $\left.\mathrm{d}^{-1}\right)$ is the Cancer Bench Mark ratio which is derived using equation 4. 


$$
C B C=(R L \times O S F \times B W) / C R
$$

Risk level (RL) is taken as $10^{-6}$, Oral Slope Factor (OSF) is measured by unit mg Kg-1 $\mathrm{d}^{-1}$,

\subsection{Data analysis and visualization}

Descriptive statistics including mean, standard deviation, range, percentage contribution and distribution frequency were generated for the milk samples gathered from Punjab districts using Microsoft Excel version 2010. Origin (Pro 8) was used to apply the Krushkal Wallis Test and multivariate statistical analysis of differences in PCBs concentration between study areas. P-value was taken as 0.05. Arc GIS (version 10.2) was used to represent the map of the area under study.

\section{Results And Discussion}

\subsection{PCBs Profile}

The concentration profile of DL-PCBs and I-PCBs of the milk samples acquired from buffaloes and cows is given in Table 1. Among all the analyzed milk samples $(n=54)$ of buffaloes $(n=26)$ and cows $(n=28)$, the total means of detected PCB congeners were 20.28 and $33.28 \mathrm{ng} \mathrm{g}^{-1}$ respectively.

PCB-156 was the predominant congener among the DL-PCBs for both buffaloes $14.02 \%$ and cows $8.59 \%$, followed by PCB-157 (11.50\% in buffaloes and $8.21 \%$ in cows). PCB-169 and 126 accounted for $1.20 \%$ and $0.73 \%$ of the congeners in buffalo's milk samples respectively whereas, PCB-118 and 169 were $7.47 \%$ and $4.77 \%$ respectively in cows. PCB-189 was not found in investigated milk samples of the cows.

Proportionally PCB-52 and PCB-28 represented $22.12 \%$ and $21.96 \%$ respectively, for the I-PCBs in buffalos' milk. In cows, PCB-52 and PCB-28 again made an almost equal contribution to the I-PCB load with $23.48 \%$ and $22.82 \%$ respectively. The percent contribution of PCB-138 to the total I-PCBs for buffaloes and cows' milk was 5.09\% and 6.04\% respectively. PCB-101 wasn't detected in the samples examined.

\subsubsection{Concentration profile of DL-PCBs in Buffaloes and Cow's Milk}

Calculation of DL-PCBs profile for the milk samples (buffaloes and cows) indicated that mono-ortho congeners (PCB-105, PCB-114, PCB-118, PCB-156, PCB-157, PCB-167 and PCB-189) showed higher values than the non-ortho PCB congeners (PCB-77, PCB-81, PCB-126 and PCB-169). $\sum_{11}$ DL-PCBs in buffaloes was $8.74 \mathrm{ng} \mathrm{g}^{-1}$ with an average $\left(0.79 \mathrm{ng} \mathrm{g}^{-1}\right)$ ranging between $0.00-2.84 \mathrm{ng} \mathrm{g}^{-1}$. Congener with the highest mean concentration was PCB-156 i.e. $2.84 \mathrm{ng} \mathrm{g}^{-1}$ (range 0.00-20.47 $\mathrm{ng} \mathrm{g}^{-1}$ ). High concentrations of PCB-156 point to the possible use and discharge of commercial PCBs as it's an important component of technical mixtures of Aroclor and Kanechlor (Kim et al. 2009, Malik et al. 2014). It was reported in a 
study conducted in New York that exposure to Aroclor 1254 was only related to PCB-156 (Seegal et al. 2011). The next highest concentrations of congeners were PCB-157 and PCB-169 with mean concentrations of $2.33 \mathrm{ng} \mathrm{g}^{-1}$ and $1.20 \mathrm{ng} \mathrm{g}^{-1}$, respectively. DL-PCB congeners are mainly thought to be produced from industrial activities including coal-burning for sintering iron ore and steel

manufacturing. The average concentration of PCB-126 in buffaloes' milk samples is $0.73 \mathrm{ng} \mathrm{g}^{-1}$ ranging between $0.00-4.11 \mathrm{ng} \mathrm{g}^{-1}$. The potency of PCB-126, however, means that it is often the main contributor (up to $90 \%$ ) to the toxicity of common PCB mixtures, (Bhavsar et al. 2008, Chirollo et al. 2018, Zhang et al. 2012) so its presence may have toxicological implications, even though it only made a small contribution in the overall PCB mixtures detected in the samples in the current study. The PCBs profile observed in the current study contrast with previous research conducted in Italy (Bertocchi et al. 2015) where PCB-118, PCB-105 and PCB-167 were reported to be present in bovine milk samples at higher concentrations i.e. $3.00 \mathrm{ng} \mathrm{g}^{-1}, 0.85 \mathrm{ng} \mathrm{g}^{-1}$ and $0.21 \mathrm{ng} \mathrm{g}^{-1}$ respectively, whereas, PCB-126, PCB-169, PCB114, PCB-156, PCB-157 and PCB-189 were present in lower concentrations (i.e. 0.03, 0.00, 0.07, 0.41, 0.10 and $0.05 \mathrm{ng} \mathrm{g}^{-1}$ ) as compared to the present work. Another Italian study conducted in 2010 also reported lower average concentrations of DL-PCBs in bovine milk, except for PCB-118 as compared to current work (Esposito et al. 2010). The study from Chile surveyed for three years, the reported mean values for DL-PCBs were $0.1113,0.079$, and $0.070 \mathrm{ng} \mathrm{g}^{-1}$ in each year. All reported PCBs congeners values were also lesser than the mean of buffalo milk samples in this study (Pizarro-Aranguiz et al. 2015). This may be explained by the previous and current exposure of PCBs to various environmental matrices of the area under study (Naqvi et al. 2018, Syed et al. 2013) and calls for action against PCBs.

In cows, the $\sum_{11}$ DL-PCBs was $14.60 \mathrm{ng} \mathrm{g}^{-1}$, range of $0.00-54.23 \mathrm{ng} \mathrm{g}^{-1}$. All analyzed milk samples were predominantly polluted with PCB-156 with the average concentration being $2.86 \mathrm{ng} \mathrm{g}^{-1}$. Congeners with the next highest mean concentrations were PCB-157 and PCB-118 with an average $2.73 \mathrm{ng} \mathrm{g}^{-1}$ and 2.49 $\mathrm{ng} \mathrm{g}^{-1}$, respectively. Other DL-PCBs which contributed significantly to cows' milk samples were PCB-169, PCB-105, PCB-81, PCB-126, PCB-114, PCB-77 and PCB-167 with mean concentrations 1.59, 1.15, 1.14, $0.92,0.89,0.70$ and $0.13 \mathrm{ng} \mathrm{g}^{-1}$ respectively. The concentration of PCB-126 was detected between $0.00-$ $9.47 \mathrm{ng} \mathrm{g}^{-1}$ in milk samples of cows. PCB-189 wasn't found in milk samples collected under this study. Comparison of results of the present study with work done in Iran in 2017 indicates that the level of PCBs in the cows' milk in Iran is much higher (Ahmadkhaniha et al. 2017). However, these studies contrast with reports from Slovakia in 2020 where the values of the 7 types of PCBs analyzed were below LOQ (Toman et al. 2020). The comparison of all congeners in the present study with previous literature for $\sum D L-P C B s$ is shown in Table S3 so that trends of contamination could be assessed which could provide preliminary data for making remedial plans in future

\subsubsection{Concentration Profile of Indicator PCBs in Milk of Buffaloes and Cow}

Stockholm Convention for POPs recommended the investigation of 6 I-PCBs (PCB-28, 52, 101, 138, 153 and 180) to characterize the contamination in milk samples (IARC 2016). None of the samples investigated in this study surpassed the provisional value for the total concentration of I-PCBs, set by the 
European Union (EU) $40 \mathrm{ng} \mathrm{g}^{-1}$ of raw milk (EU 2011). $\sum$ I-PCBs mean concentration in the milk samples of buffaloes is $1.92 \mathrm{ng} \mathrm{g}^{-1}$ ranging between $0.00-4.49 \mathrm{ng} \mathrm{g}^{-1}$. Congener profile in buffaloes showed that PCB-52 and PCB-28 were present at the highest average values $4.49 \mathrm{ng} \mathrm{g}^{-1}$ and $4.45 \mathrm{ng} \mathrm{g}^{-1}$, respectively with percentage contribution $22.12 \%$ and $21.96 \%$. These high values may be indicative of nearby waste dumping sites, agricultural activities, and pigments industries as these are probable main sources of environmental contamination (Hu \&Hornbuckle 2010, IARC 2016). The next highest I-PCB congener concentrations were PCB-153, 138 and 180 with mean concentrations $1.10 \mathrm{ng} \mathrm{g}^{-1}, 1.03 \mathrm{ng} \mathrm{g}^{-1}$ and $0.47 \mathrm{ng}$ $\mathrm{g}^{-1}$. These higher chlorinated PCBs stay in the environment for long durations as they are difficult to degrade, hence they might be considered as indicators of past exposure (Komprda et al. 2019). Manufacturing plants of iron and steel were also reported as potential sources for I-PCBs (Baek et al. 2010). PCB-101 wasn't found in the buffaloes' milk samples of the present study. $\sum$ I-PCBs average in cows was $3.11 \mathrm{ng} \mathrm{g}^{-1}$ range $0.00-7.81 \mathrm{ng} \mathrm{g}^{-1}$. In the cows' milk samples, PCB-52 showed the highest mean values $7.81 \mathrm{ng} \mathrm{g}^{-1}$ tailed by PCB-28 with a mean concentration $7.59 \mathrm{ng} \mathrm{g}^{-1}$. The percent contribution of these congeners was $23.48 \%$ and $22.82 \%$, respectively. PCB-138 and 153 showed mean values $2.01 \mathrm{ng} \mathrm{g}^{-}$ 1 and $1.26 \mathrm{ng} \mathrm{g}^{-1}$, respectively. PCB-101 and PCB-180 weren't detected in the cows' milk samples of the study areas tested in this study.

Research work done in California in 2017 presented lower values of I-PCBs when compared with the present study except for PCB-101 which wasn't detected in current work (mean $=0.67 \mathrm{ng} \mathrm{g}^{-1}$ in California). In this study, out of all the analyzed I-PCBs in the milk samples, PCB-138, PCB-101 and 118 concentrations were the highest (Chen et al. 2017). The differences in I-PCB levels reported in the present study in comparison to previously published literature might be due to differences in season. Rainy conditions are known to change PCB levels in soil and fodder crops, also the feeding practices of buffaloes and cows differ greatly between countries and this might have impacted levels and detection of PCB congeners. Another important factor that could influence the PCB contamination levels in milk is the days in lactation of the buffaloes and cows (Chen et al. 2017, Pérez et al. 2012, Roger Wabeke \&Weinstein 1995). Table S4 shows the current study and previously published literature comparison for IPCBs.

\subsection{Toxic Equivalency of Dioxin-like PCBs}

PCB congeners could be characterized concerning their extent of chlorination, substitution tendency, and affinity for binding to receptors. PCBs that show high attraction to aryl hydrocarbon receptor (AhR) is termed as DL-PCBs (Van den Berg et al. 2006). The Toxic Equivalency Factor (TEF) is assigned to congeners after comparing with 2,3,7,8-tetrachlorodibenzo-p-dioxin (TCDD) which is extremely noxious among all dioxins, hence a toxic potency 1 i.e. TEF 1 is assigned (Chirollo et al. 2018). The concentration value of each congener was multiplied with its corresponding TEF and resulting TCDD equivalents express toxic equivalents validated through the WHO (Van den Berg et al. 2006). According to regulation (EC) No 1881/2006, milk and other dairy products shouldn't contain more than $0.0055 \mathrm{ng} \mathrm{TEQ}^{-1}$ fat DLPCBs (Ahmadkhaniha et al. 2017). TEQ values, investigated for DL-PCBs (PCB-77, 81, 105, 114, 118, 126, 
$156,157,167,169$ and 189 ) are given in Table 2 . The sum of $\sum$ DL-PCBs expressed as WHO $\mathrm{TEQ}_{2005}$ forbuffaloes $\left(0.11 \mathrm{ng} \mathrm{g}^{-1}\right)$ and cows $\left(0.14 \mathrm{ng} \mathrm{g}^{-1}\right)$ recorded for the current study exceeded the recommended maximum limit.In the milk samples of both buffaloes and cows, PCB-126 has the highest TEQ values i.e. $0.07 \mathrm{ng} \mathrm{g}^{-1}$ and $0.09 \mathrm{ng} \mathrm{g}^{-1} \mathrm{TEQ}_{2005}$, respectively. PCB-169 has a value at the secondhighest level in buffaloes and cows i.e. $0.03 \mathrm{ng} \mathrm{g}^{-1}$ and $0.05 \mathrm{ng} \mathrm{g}^{-1} \mathrm{TEQ}_{2005}$ respectively. These values exceed the given limit of $0.0055 \mathrm{ng} \mathrm{g}^{-1}$ by (Regulation 2011). ThePCB TEQ values seen in the current study are higher than previous reports such as $0.00051 \mathrm{ng} \mathrm{g}^{-1}$ in Polish milk samples taken from cows (Piskorska-Pliszczynska et al. 2012) and 0.00389 - 0.00595 ng TEQ g $^{-1}$ fat for DL-PCBs in Italian buffaloes milk samples (Chirollo et al. 2018).

\subsection{Spatial Dispersal Patterns and Sources of PCBs in Bovine Milk}

The distribution patterns of PCBs in buffaloes and cows' samples from the 8 districts of Punjab, Pakistan included in the current study are depicted in Fig. 1 ( $a$ and b), whereas, percentage contributions of $\sum$ DLPCBs and $\sum$ I-PCBs in different districts of Punjab are shown in Fig 2 ( $a$ and $b$ ) respectively. The PCBs profiles differed significantly $(p<0.05)$ among the studied districts. The highest average $\sum$ PCB concentrations after analyzing all samples from buffaloes and cows were observed in Okara district. The investigated high levels of PCBs in the milk of this area might be due to adjacent highway and the industries (cotton, pharmaceutical, marble and granite, plastic, zari, and agro factories) present within 5 $\mathrm{Km}$ of the dairy farm sampled (maps 2021). Being an agricultural area, past usage of PCBs-based pesticides, wood, and solid waste burning practices may also have added to the PCBs level of this site (Naqvi et al. 2020). The second highest values in buffalo contaminated milk were observed in Multan making up $15.44 \%$ of the total $\Sigma$ PCBs concentration. In cows' milk, second place was held by Sialkot making up $18.19 \%$ of total $\Sigma$ PCBs concentrations for cow milk samples in the current study. Lighter PCB homologs (mono to hexa chlorobiphenyls) are linked to few common practices including the burning of agricultural waste, cow dung, and wood. (Balasubramani et al. 2014, Weber et al. 2018).

In milk samples of buffaloes, $\sum$ DL-PCBs were predominant at district Lahore with $21.39 \%$ contribution. It might be due to heavy traffic, urbanization, dense population and urbanization in Lahore (Mumtaz et al. 2016). Another study highlighted the adverse PCB contamination in this site especially near industrial and waste dumping areas (Syed et al. 2014). It was followed by Multan and Faisalabad with $17.45 \%$ and $16.86 \%$ contributions. In cows, the highest $\sum$ DL-PCBs were found in Sialkot followed by Gujrat and Okara with the contribution of $21.65 \%, 21.17 \%$ and $20.34 \%$ respectively. Many industrial setups are present in the city and surrounding areas of Sialkot district, they might release PCBs into the surrounding environment which could be a reason for high results (Mahmood et al. 2014b). Among IPCBs (Fig. 2 (b), predominant values were detected at district Okara which was followed by Gujrat by percentages $23.06 \%$ and $19.59 \%$ in the milk of buffaloes, in the same way, cows' milk also showed predominant values in district Okara tailed by Kasur and Sialkot by percentage contribution $21.08 \%$, $16.68 \%$ and $15.49 \%$ respectively. A generalized view is that bovine animals take up PCBs primarily from the feed but there are other known and unknown sources as well which might contribute towards the 
PCBs levels (McLachlan 1993). District Multan also contributed significantly with $14.26 \%$ and $14.52 \%$ of I-PCBs in buffaloes and cows in the province Punjab. This is strengthened by another study, which showed air samples from Multan urban areas with the highest PCB values (Ali et al. 2015). Urban activities in the cities could also be a major source of atmospheric PCB emissions (Ali et al. 2015) and PCBs atmospheric deposition may affect plants and livestock feed greatly (Toman et al. 2020). In the Sahiwal district, within $20 \mathrm{Km}$ distance of the sampled dairy farm, no industrial area or other large-scale commercial activity was identified. Unintentional sources of PCBs emissions including wood and coal combustion (Gullett et al. 2003, Lee et al. 2005), steel plants (Odabasi et al. 2009), e-waste (Wang et al. 2016), and incineration of domestic solid waste (Kim \&Osako 2004) could be the reason of contamination of the milk samples. The difference between values observed in buffaloes and cows could be due to the variation in food sources and the surrounding environment. Moreover, eating practices of buffaloes and cows differ between locations by their probable impacts on various levels and PCBs exposure. Dumping of residential waste, combustion of waste, electric equipment, PVS, vehicle fuel openly, and other chemical processes may be practiced in the majority part of study areas. PCBs found in human beings greatly depend upon lifestyle and the degree of industrialization. In a study conducted on the Indus River basin, the highest soil PCB concentrations were observed at the agricultural sites (Ali et al. 2015). When the main source of emissions like incinerators, dumpsites and dielectric fluids are not present in the study area (Pérez et al. 2012) then the levels of PCB should fall in permissible limits range. Nevertheless, the current results point towards the existence of other unintended sources and emissions. Thus, it is recommended to maintain surveillance on products used for agriculture and continuous monitoring.

\subsection{Health Risk Assessment}

\subsubsection{Non-Carcinogenic risk}

None of the milk samples show EDI exceeding the corresponding ADI limits for both children and adults. For each investigated analyte, the EDI values were higher in children than adults for all milk samples. Among DL-PCBs, PCB-126 showed the highest EDI values 0.72 and $1.57 \mathrm{ng} \mathrm{Kg}^{-1} \mathrm{~d}^{-1}$ (for adults and children) using buffaloes' milk whereas 0.92 and $2.00 \mathrm{ng} \mathrm{Kg}^{-1} \mathrm{~d}^{-1}$ (adults and children) using cows' milk, respectively but lower than ADI $5.5 \mathrm{ng} \mathrm{Kg}^{-1}$ throughout this work (Table 3). This high value of PCB126 may be because of its non-metabolic degradation and these results were also following a study conducted on buffaloes in Italy (Chirollo et al. 2018). ADI of DL-compounds in Dutch people age between 20-25 years, 2.3 and $2.0 \mathrm{pg}$ TEQ Kg${ }^{-1} \mathrm{BW} \mathrm{d}^{-1}$ males and females respectively was found by (Patandin 1999). Two groups of children were studied ( $1-5$ years) and (6 and 10 years), the EDI was higher in young ones. Similar results were presented by (Wittsiepe et al. 2001) in a similar study conducted in Germany with children 14 to 47 months of age.

No sample in the current study crossed the ADI limits of $40000 \mathrm{ng} \mathrm{Kg}^{-1}$ for the I-PCBs under study. PCB-28 and PCB-52 in buffaloes' milk showed EDI values $44.53 \& 44.86 \mathrm{ng} \mathrm{kg}^{-1} \mathrm{~d}^{-1}$ in adult people and $96.45 \& 97.17 \mathrm{ng} \mathrm{Kg}^{-1} \mathrm{~d}^{-1}$ in children whereas, cows' milk $75.94 \& 78.14 \mathrm{ng} \mathrm{Kg}^{-1} \mathrm{~d}^{-1}$ in adultswhereas 
164.49 \& $169.26 \mathrm{ng} \mathrm{Kg}^{-1} \mathrm{~d}^{-1}$ in children, respectively. PCB-138 showed a value (43.54 $\mathrm{ng} \mathrm{Kg}^{-1} \mathrm{~d}^{-1}$ ) aimed at kids consuming cows' milk (Table 3). PCB-28 are reported to cause developmental neurotoxicity in humans above the ADI (Leijs et al. 2019). In two studies conducted in Brazil on I-PCBs, the EDI value of $\sum$ I-PCBs in raw milk was $1.21 \mathrm{ng} \mathrm{Kg}^{-1}$ and in milk powder was found to be $110 \mathrm{ng} \mathrm{Kg}^{-1}$, both results were lower than the present study values for I-PCBs (Costabeber et al. 2018, Heck et al. 2007).

\subsubsection{Carcinogenic risk}

The potential of PCB contaminated milk to cause cancer is based on cancer benchmark concentration $(\mathrm{CBC})$. Cancer risk, categorized to be one in a million and hazard ratio $(H R>1)$ is estimated from CBC for analyzing cancer-causing effects in humans (Dougherty et al. 2000). For detailed analysis vulnerable groups especially children should be included in the process of assessment of the risk. The uptake of the pollutants may vary with age. The food and body weight ratio of children is higher than adults so a large amount of DL-PCBs could be ingested. As the children grow up, the dose per unit body weight decreases whereas the consumption per day increases and remains almost the same over 20 years of age (WHO 2000).

Table 4 represents the results calculated for carcinogenic risk based on the current study. The consumption of milk from different areas of the Punjab province that is contaminated with the $\sum \mathrm{DL}$ PCBs does not pose a cancer threat to adults and kids as the HQ calculated was less than 1 . But the results for $\sum$ PCBs including both $\sum$ DL-PCBs and $\sum$ I-PCBs showed a cancer risk for kids in milk samples collected from both buffaloes and cows as the HQ was greater than 1. The HQ values exceeded one for PCBs indicating high risk for infants (Devanathan et al. 2011).

Hence, it could be said that milk from Punjab, Pakistan is safe to use for adults but it may cause risks for children. Previously, carcinogenic risk due to consumption of rice contaminated with PCBs was also reported in Punjab province (Mumtaz et al. 2016). As the significant level of PCBs is reported and detected in Pakistan's environmental matrices, therefore, implementation of educational and awareness activities in the study area might increase the knowledge of local people about the risks and hazards associated with the release of PCBs into the environment, including aspects like major emission sources and how exposure of these could be avoided.

\section{Conclusion}

The current study showed values of $\sum$ DL-PCBs for buffaloes and cows' milk samples to be $0.11 \mathrm{ng} \mathrm{g}^{-1}$ and $0.23 \mathrm{ng} \mathrm{g}^{-1}$ respectively. These investigated values are higher than the standard $5.5 \mathrm{pg} \mathrm{g}^{-1}$ given by the EU commission regulation. Current findings indicate the regional variability of PCB profiles and sources in bovine milk. District Okara showed highest levels of $\sum$ DL-PCBs and $\sum$ I-PCBs in bovine milk samples. The potential non-carcinogenic adverse health effects were calculated and should be emphasized in the sampling areas. Possible cancer risk posed to children is significant. Intentional and unintentional emission of PCBs from industries, burning of wood and coal and poor waste disposal 
techniques appear to be the main source for PCBs in bovine milk in most sampling areas. The authors recommend continuous monitoring and reduction of PCBs in the environment to minimize exposure.

\section{Declarations}

\section{- Authors' contributions}

Saman Sana: Conceptualization, Data curation, Formal analysis, Funding acquisition, Investigation, Methodology, Resources, Roles/ Writing - original draft, Writing - review \& editing; Abdul Qadir: Conceptualization, Funding acquisition, Investigation, Methodology, Project administration, Supervision, Resources, Validation, Visualization, Roles/Writing - original draft, Writing - review \& editing; Neil P Evans: Funding acquisition, Methodology, Resources, Analytical support, Software, Validation, Visualization, Writing - review \& editing; Mehvish Mumtaz: Investigation, Data curation, Formal analysis, Visualization, review \& editing; Ambreena Mubashir: Methodology, Data curation, GIS analysis; Maps development, Visualization, review \& editing; Amjad Khan; Visualization, Sample Collection; Review \& editing; Saif-urRehman Kashif; Visualization, Methodology validation; Sample Collection; Review \& editing; Habib ur Rehman; Visualization, Methodology, Validation, review \& editing.

\section{- Acknowledgements}

The authors acknowledge the people who helped during field sampling from Punjab Pakistan and Professor Neil P. Evans for the provision of sample analytical support at the School of Engineering and Institute of Biodiversity, Animal Health and Comparative Medicine, University of Glasgow, Glasgow, Scotland, for their assistance during GCMS analysis. The first author is also thankful to the Scottish Government for providing a research travel grant. The authors acknowledge institutional support from the University of the Punjab, Lahore, Pakistan

\section{- Availability of data and materials}

All data generated or analyzed during this study are included in this published article are available in the research institute of standard. Materials are available, too.

- Funding

Pakistan Scottish PhD Research Travel Grant for Women, 2019

\section{- Ethics approval and consent to participate}

Ethical approval was taken fromAnimal Ethics Committee of the University of the Punjab, chaired by Dr. Ahmad Usman Zafar.

- Competing interests and Authors' information (optional) 
The authors declare that they have no known competing financial interests or personal relationships that could have appeared to influence the work reported in this paper. Furthermore, the authors declare no conflict of interest

\section{- Consent for publication}

We the undernamed declare that this manuscript is original, has not been published before and is not currently being considered for publication elsewhere. We confirm that the manuscript has been read and approved by all named authors and that there are no other persons who satisfied the criteria for authorship but are not listed. We further confirm that the order of authors listed in the manuscript has been approved by all of us. We understand that the Corresponding Author (CA) is the sole contact for the Editorial process. He is responsible for communicating with the other authors about progress, submissions of revisions and final approval of proofs.

\section{References}

1. Adeleye AOS, M. B. Oyekunle, J. A. O. (2019): Dietary exposure assessment of organochlorine pesticides in two commonly grown leafy vegetables in South-western Nigeria. Heliyon 5, e01895

2. Aguilera-Luiz MM, Plaza-Bolanos, P., Romero-Gonzalez, R., Vidal, J. L., Frenich, A. G. (2011): Comparison of the efficiency of different extraction methods for the simultaneous determination of mycotoxins and pesticides in milk samples by ultra high-performance liquid chromatographytandem mass spectrometry. Anal Bioanal Chem 399, 2863-75

3. Ahmadkhaniha R, Nodehi RN, Rastkari N, Aghamirloo HM (2017): Polychlorinated biphenyls (PCBs) residues in commercial pasteurized cows' milk in Tehran, Iran. J Environ Health Sci Eng 15,15

4. Ali U, Syed JH, Mahmood A, Li J, Zhang G, Jones KC, Malik RN (2015): Influential role of black carbon in the soil-air partitioning of polychlorinated biphenyls (PCBs) in the Indus River Basin, Pakistan. Chemosphere 134, 172-80

5. Baars AJ, Bakker MI, Baumann RA, Boon PE, Freijer JI, Hoogenboom LA, Hoogerbrugge R, van Klaveren JD, Liem AK, Traag WA, de Vries J (2004): Dioxins, dioxin-like PCBs and non-dioxin-like PCBs in foodstuffs: occurrence and dietary intake in The Netherlands. Toxicol Lett 151, 51-61

6. Baek S-Y, Choi S-D, Park H, Kang J-H, Chang Y-S (2010): Spatial and Seasonal Distribution of Polychlorinated Biphenyls (PCBs) in the Vicinity of an Iron and Steel Making Plant. Environ. Sci. Technol. 44, 3035-3040

7. Balasubramani A, Howell NL, Rifai HS (2014): Polychlorinated biphenyls (PCBs) in industrial and municipal effluents: concentrations, congener profiles, and partitioning onto particulates and organic carbon. Sci Total Environ 473-474, 702-13

8. Bányiová K, Černá M, Mikeš O, Komprdová K, Sharma A, Gyalpo T, Čupr P, Scheringer M (2017): Long-term time trends in human intake of POPs in the Czech Republic indicate a need for continuous monitoring. Environ Int 108, 1-10 
9. Baqar M, Sadef Y, Ahmad SR, Mahmood A, Qadir A, Aslam I, Li J, Zhang G (2017): Occurrence, ecological risk assessment, and spatio-temporal variation of polychlorinated biphenyls (PCBs) in water and sediments along River Ravi and its northern tributaries, Pakistan. Environ Sci Pollut Res Int 24, 27913-27930

10. Bertocchi L, Ghidini S, Fedrizzi G, Lorenzi V (2015): Case-study and risk management of dioxins and PCBs bovine milk contaminations in a high industrialized area in Northern Italy. Environ Sci Pollut Res Int 22, 9775-85

11. Bhavsar SP, Reiner EJ, Hayton A, Fletcher R, MacPherson K (2008): Converting Toxic Equivalents (TEQ) of dioxins and dioxin-like compounds in fish from one Toxic Equivalency Factor (TEF) scheme to another. Environ Int 34, 915-21

12. Binelli A, Provini A (2004): Risk for human health of some POPs due to fish from Lake Iseo. Ecotoxicol Environ Saf 58, 139-45

13. Breivik K, Sweetman A, Pacnya JM, KC J (2002): Towards a global historical inventory for selected PCB congeners - a mass balance approach 2. Emissions. Sc Tot Environ 290, 199-224

14. Chen X, Lin Y, Dang K, Puschner B (2017): Quantification of Polychlorinated Biphenyls and Polybrominated Diphenyl Ethers in Commercial Cows' Milk from California by Gas Chromatography-Triple Quadruple Mass Spectrometry. PloS one 12, e0170129

15. Chirollo C, Ceruso M, Pepe T, Vassallo A, Marrone R, Severino L, Anastasio A (2018): Levels and congeners distribution of dioxins, furans and dioxin-like PCBs in buffaloes adipose tissues sampled in vivo and milk. CYTA-J Food 16, 1109-1114

16. Costabeber IH, Coelho AN, Schwanz TG, Weis GCC, Carpilovsky CK (2018): Levels of polychlorinated biphenyls (PCBs) in whole milk powderand estimated daily intake for a population of children. Ciência Rural 48

17. Deti H, Hymete A, Bekhit AA, Mohamed AM, Bekhit Ael D (2014): Persistent organochlorine pesticides residues in cow and goat milks collected from different regions of Ethiopia. Chemosphere 106, 70-4

18. Devanathan G, Isobe T, Subramanian A, Asante KA, Natarajan S, Palaniappan P, Takahashi S, Tanabe S (2011): Contamination Status of Polychlorinated Biphenyls and Brominated Flame Retardants in Environmental and Biota Samples from India. In: Kawaguchi M et al. (Editors), Interdisciplinary Studies on Environmental Chemistry-Environmental Pollution and Ecotoxicology. Terrapub, pp. 269-277

19. Dewan P, Jain V, Gupta P, Banerjee BD (2013): Organochlorine pesticide residues in maternal blood, cord blood, placenta, and breastmilk and their relation to birth size. Chemosphere 90 , 1704-10

20. Dougherty CP, Henricks Holtz S, Reinert JC, Panyacosit L, Axelrad DA, Woodruff TJ (2000): Dietary exposures to food contaminants across the United States. Environ Res 84, 170-85

21. EFSA (2018): Risk for animal and human health related to the presence of dioxins and dioxinlike PCBs in feed and food. 
22. EPA (2004): Polychlorinated Biphenyls (PCBs) ID-Definitions

23. EPA U (2021): Polychlorinated Biphenyls (PCBs). United States Environmental Protection Agency

24. Eqani SA, Malik RN, Katsoyiannis A, Zhang G, Chakraborty P, Mohammad A, Jones KC (2012): Distribution and risk assessment of organochlorine contaminants in surface water from River Chenab, Pakistan. Journal of Environmental Monitoring 14, 1645-1654

25. Eqani SA, Malik RN, Cincinelli A, Zhang G, Mohammad A, Qadir A, Rashid A, Bokhari H, Jones KC, Katsoyiannis A (2013): Uptake of organochlorine pesticides (OCPs) and polychlorinated biphenyls (PCBs) by river water fish: the case of River Chenab. Sci Total Environ 450-451, 83-91

26. Eqani SA, Cincinelli A, Mehmood A, Malik RN, Zhang G (2015): Occurrence, bioaccumulation and risk assessment of dioxin-like PCBs along the Chenab river, Pakistan. Environ Pollut 206, 688-95

27. Esposito M, Serpe FP, Neugebauer F, Cavallo S, Gallo P, Colarusso G, Baldi L, lovane G, Serpe L (2010): Contamination levels and congener distribution of PCDDs, PCDFs and dioxin-like PCBs in buffalo's milk from Caserta province (Italy). Chemosphere 79, 341-8

28. EU (2011): Regulation (EC) No 1259/2011 of 2 December 2011 amending Regulation (EC) No $1881 / 2006$ as regards maximum levels for dioxins, dioxin-like PCBs and non dioxin-like PCBs in foodstuffs. In: Official Journal of the European Union L, 18. (Hrsg.)

29. Fadaei H, Watson A, Place A, Connolly J, Ghosh U (2015): Effect of PCB bioavailability changes in sediments on bioaccumulation in fish. Environ. Sci. Technol. 49, 12405-12413

30. FAO (2019): Dairy and dairy products, OECD-FAO Agricultural Outlook 2019-2028

31. FAO/WHO (2018): Proposed draft revision of the code of practice for the prevention and reduction of dioxins and dioxin-like pcbs in food and feed

32. Focant JF, Pirard C, Massart AC, De Pauw E (2003): Survey of commercial pasteurised cows' milk in Wallonia (Belgium) for the occurrence of polychlorinated dibenzo-p-dioxins, dibenzofurans and coplanar polychlorinated biphenyls. Chemosphere 52, 725-733

33. Gong W, Fiedler H, Liu X, Wang B, Yu G (2017): Reassessment and update of emission factors for unintentional dioxin-like polychlorinated biphenyls. Sci Total Environ 605-606, 498-506

34. Gullett BK, Touati A, Hays MD (2003): PCDD/F, PCB, HxCBz, PAH, and PM Emission Factors for Fireplace and Woodstove Combustion in the San Francisco Bay Region. Environ. Sci. Technol. $37,1758-1765$

35. Heck MC, Sifuentes dos Santos J, Bogusz Junior S, Costabeber I, Emanuelli T (2007): Estimation of children exposure to organochlorine compounds through milk in Rio Grande do Sul, Brazil. Food Chemistry 102, 288-294

36. Hu Dn, Hornbuckle K (2010): Inadvertent Polychlorinated Biphenyls in Commercial Paint Pigments. Environ. Sci. Technol 44, 2822-2827

37. Hulin M, Sirot V, Vasseur P, Mahe A, Leblanc JC, Jean J, Marchand P, Venisseau A, Le Bizec B, Riviere G (2020): Health risk assessment to dioxins, furans and PCBs in young children: The first 
French evaluation. Food and chemical toxicology : an international journal published for the British Industrial Biological Research Association 139, 111292

38. IARC (2016): IARC Working Group on the Evaluation of Carcinogenic Risks to Humans.

Polychlorinated Biphenyls and Polybrominated Biphenyls. Lyon (FR): International Agency for Research on Cancer; 2016.

39. IARC IAfRoC 2012: Chemical agents and related occupations.

40. Ibigbami OA, Aiyesanmi AF, Adesina AJ, Popoola OK (2019): Occurrence and Levels of Chlorinated Pesticides Residues in Cow Milk: A Human Health Risk Assessment. JACEN 08, 5867

41. Ishaq Z, Sajid MW, Saleem S, Mehmood A, Ali L, Hussain A (2018): A Perspective on Organochlorine Pesticide Residues in Milk Produced in Pakistan. ECNU 13.6, 9

42. Kabir ER, Rahman MS, Rahman I (2015): A review on endocrine disruptors and their possible impacts on human health. Environ Toxicol Pharmacol 40, 241-58

43. Kerst M, Waller U, Reifenhäuser W, Körner W (2004): Carry-Over Rates of Dioxin-like PCB from Grass to Cows' Milk. Organohalogen compounds 66

44. Kim K-S, Lee SC, Kim K-H, Shim WJ, Hong SH, Choi KH, Yoon JH, Kim J-G (2009): Survey on organochlorine pesticides, PCDD/Fs, dioxin-like PCBs and HCB in sediments from the Han river, Korea. Chemosphere 75, 580-587

45. Kim YJ, Osako M (2004): Investigation on the humification of municipal solid waste incineration residue and its effect on the leaching behavior of dioxins. Waste management $24,815-23$

46. Komprda J, Komprdova K, Dominguez-Romero E, Mikes O, Rihackova K, Cupr P, Cerna M, Scheringer M (2019): Dynamics of PCB exposure in the past 50years and recent high concentrations in human breast milk: Analysis of influencing factors using a physiologically based pharmacokinetic model. Sci Total Environ 690, 388-399

47. Lamarche B, Givens DI, Soedamah-Muthu S, Krauss RM, Jakobsen MU, Bischoff-Ferrari HA, Pan A, Després JP (2016): Does Milk Consumption Contribute to Cardiometabolic Health and Overall Diet Quality? The Canadian journal of cardiology 32, 1026-32

48. Larsson SC, Crippa A, Orsini N, Wolk A, Michaëlsson K (2015): Milk Consumption and Mortality from All Causes, Cardiovascular Disease, and Cancer: A Systematic Review and Meta-Analysis. Nutrients 7, 7749-63

49. Lee RGM, Coleman P, Jones JL, Jones KC, Lohmann R (2005): Emission Factors and Importance of PCDD/Fs, PCBs, PCNs, PAHs and PM10 from the Domestic Burning of Coal and Wood in the U.K. Environ. Sci. Technol. 39, 1436-1447

50. Leijs MM, Gan L, De Boever P, Esser A, Amann PM, Ziegler P, Fietkau K, Schettgen T, Kraus T, Merk HF, Baron JM (2019): Altered Gene Expression in Dioxin-Like and Non-Dioxin-Like PCB Exposed Peripheral Blood Mononuclear Cells. Int J Environ Res Public Health 16, 2090

51. Lind PM, Salihovic S, Stubleski J, Kärrman A, Lind L (2019): Association of Exposure to Persistent Organic Pollutants With Mortality Risk: An Analysis of Data From the Prospective 
Investigation of Vasculature in Uppsala Seniors (PIVUS) Study. JAMA network open 2, e193070

52. Lyon $F$ (2016): Polychlorinated biphenyls and polybrominated biphenyls, IARC monographs on the evaluation of carcinogenic risks to humans. In: International Agency for Research on Cancer WHO (Hrsg.)

53. Mahmood A, Malik RN, Li J, Zhang G (2014a): Levels, distribution profile, and risk assessment of polychlorinated biphenyls (PCBs) in water and sediment from two tributaries of the River Chenab, Pakistan. Environ Sci Pollut Res Int 21, 7847-55

54. Mahmood A, Syed JH, Malik RN, Zheng Q, Cheng Z, Li J, Zhang G (2014b): Polychlorinated biphenyls (PCBs) in air, soil, and cereal crops along the two tributaries of River Chenab, Pakistan: concentrations, distribution, and screening level risk assessment. Sci Total Environ 481, 596-604

55. Malik RN, Mehboob F, Ali U, Katsoyiannis A, Schuster JK, Moeckel C, Jones KC (2014): Organohalogenated contaminants (OHCs) in the sediments from the Soan River, Pakistan: OHCs(adsorbed TOC) burial flux, status and risk assessment. Sci Total Environ 481, 343-351

56. Malisch R, Kotz A (2014): Dioxins and PCBs in feed and food--review from European perspective. Sci Total Environ 491-492, 2-10

57. Mamontova EA, Tarasova EN, Mamontov AA, Kuzmin MI, McLachlan MS, Khomutova M (2007): The influence of soil contamination on the concentrations of PCBs in milk in Siberia. Chemosphere 67, S71-8 maps G (2021):

58. McLachlan MS (1993): Mass balance of polychlorinated biphenyls and other organochlorine compounds in a lactating cow. Journal of Agricultural and Food Chemistry 41, 474-480

59. Meng J, Hong S, Wang T, Li Q, Yoon SJ, Lu Y, Giesy JP, Khim JS (2017): Traditional and new POPs in environments along the Bohai and Yellow Seas: An overview of China and South Korea. Chemosphere 169, 503-515

60. Mumtaz M, Mehmood A, Qadir A, Mahmood A, Malik RN, Sabir AM, Li J, Zhang G (2016): Polychlorinated biphenyl (PCBs) in rice grains and straw; risk surveillance, congener specific analysis, distribution and source apportionment from selected districts of Punjab Province, Pakistan. Sci Total Environ 543, 620-627

61. Naqvi A, Qadir A, Mahmood A, Baqar M, Aslam I, Sajid F, Mumtaz M, Li J, Zhang G (2018): Quantification of polychlorinated biphenyl contamination using human placenta as biomarker from Punjab Province, Pakistan. Environ Sci Pollut Res Int 25, 14551-14562

62. Naqvi A, Qadir A, Mahmood A, Baqar M, Aslam I, Jamil N, Mumtaz M, Saeed S, Zhang G (2020): Screening of human health risk to infants associated with the polychlorinated biphenyl (PCB) levels in human milk from Punjab Province, Pakistan. Environ Sci Pollut Res Int 27, 6837-6850

63. Odabasi M, Bayram A, Elbir T, Seyfioglu R, Dumanoglu Y, Bozlaker A, Demircioglu H, Altiok H, Yatkin S, Cetin B (2009): Electric Arc Furnaces for Steel-Making: Hot Spots for Persistent Organic Pollutants. Environ. Sci. Technol. 43, 5205-5211

64. Pakistan Economic Survey - 2018: Pakistan economic survey 2017-18 
65. Patandin S 1999: Effects of environmental exposure to polychlorinated biphenyls and dioxins on growth and development in young children., Erasmus University Rotterdam

66. Pérez JJ, León SVy, Gutiérrez R, López Y, Faure R, Escobar A (2012): Polychlorinated biphenyls (PCBs) residues in milk from an agroindustrial zone of Tuxpan, Veracruz, Mexico. Chemosphere $89,404-408$

67. Perisic P, Bogdanovic V, Mekic C, Ruzic-Muslic D, Stanojevic D, Popovac M, Stepic S (2015): The importance of buffalo in milk production and buffalo population in Serbia. Biotechnol. Anim. Husb. 31, 255-263

68. Piskorska-Pliszczynska J, Mikołajczyk S, Maszewski S, Bany MW, Góraj Ł (2012): Study of dioxin levels in raw milk of cows and goats in Poland. Proceedings of ECOpole 6

69. Pizarro-Aranguiz N, Galban-Malagon CJ, Ruiz-Rudolph P, Araya-Jordan C, Maddaleno A, San Martin B (2015): Occurrence, variability and human exposure to Polychlorinated Dibenzo-pdioxins (PCDDs), Polychlorinated Dibenzofurans (PCDFs) and Dioxin-Like Polychlorinated Biphenyls (DL-PCBs) in dairy products from Chile during the 2011-2013 survey. Chemosphere $126,78-87$

70. Regulation C (2011): Commission regulation (EU) No 1259/2011 of amending Regulation (EC) No 1881/2006 as regards maximum levels for dioxins, dioxin-like PCBs and non dioxin-like PCBs in foodstuffs., No 1259/2011

71. Roger Wabeke, Weinstein R (1995): Case Study 36: Polychlorinated Biphenyl (PCB) Toxicity. In: Medicine lo (Editor), Environmental Medicine: Integrating a Missing Element into Medical Education. The National Academies Press, Washington, DC

72. Rosinska A, Karwowska B (2017): Dynamics of changes in coplanar and indicator PCB in sewage sludge during mesophilic methane digestion. J Hazard Mater 323, 341-349

73. Roveda AM, Veronesi L, Zoni R, Colucci ME, Sansebastiano G (2006): [Exposure to polychlorinated biphenyls (PCBs) in food and cancer risk: recent advances]. Ig Sanita Pubbl 62, 677-96

74. Sajid MW, Shamoon M, Randhawa MA, Asim Ma, Chaudhry AS (2016): The impact of seasonal variation on organochlorine pesticide residues in buffalo and cow milk of selected dairy farms from Faisalabad region. Environ Monit Assess 188, 589

75. Sana S, Qadir A, Mumtaz M, Evans NP, Ahmad SR (2021): Spatial trends and human health risks of organochlorinated pesticides from bovine milk; a case study from a developing country, Pakistan. Chemosphere 276, 130110

76. Sarode AR, Kalyankar SD, Deosarkar SS, Khedkar CD, Pawshe RD (2016): Milk: Role in the Diet. In: Caballero B, Finglas PM , Toldrá F (Editors), Encyclopedia of Food and Health. Academic Press, Oxford, pp. 736-740

77. Seegal RF, Fitzgerald EF, Hills EA, Wolff MS, Haase RF, Todd AC, Parsons P, Molho ES, Higgins DS, Factor SA, Marek KL, Seibyl JP, Jennings DL, McCaffrey RJ (2011): Estimating the half-lives 
of PCB congeners in former capacitor workers measured over a 28-year interval. Journal of exposure science \& environmental epidemiology 21, 234-46

78. Sewart A, Jones KC (1996): A survey of PCB congeners in U.K. cows' milk. Chemosphere 32, 2481-92

79. Sohail M, Eqani S, Podgorski J, Bhowmik AK, Mahmood A, Ali N, Sabo-Attwood T, Bokhari H, Shen H (2018): Persistent organic pollutant emission via dust deposition throughout Pakistan: Spatial patterns, regional cycling and their implication for human health risks. Sci Total Environ $618,829-837$

80. Son MH, Kim JT, Park H, Kim M, Paek OJ, Chang YS (2012): Assessment of the daily intake of 62 polychlorinated biphenyls from dietary exposure in South Korea. Chemosphere 89, 957-63

81. Sosan MO, J. (2017): Organochlorine Pesticide Residue Levels and Potential Human Health Risks in Kolanuts from Selected Markets in Osun State, Southwestern Nigeria. Asian J. Chem. Sci. 2, 1-11

82. Syed JH, Malik RN, Li J, Zhang G, Jones KC (2013): Levels, distribution and air-soil exchange fluxes of polychlorinated biphenyls (PCBs) in the environment of Punjab Province, Pakistan. Ecotoxicol Environ Saf 97, 189-95

83. Syed JH, Malik RN, Li J, Chaemfa C, Zhang G, Jones KC (2014): Status, distribution and ecological risk of organochlorines (OCs) in the surface sediments from the Ravi River, Pakistan. Sci Total Environ 472, 204-11

84. Toman R, Pšenková M, Tančin V (2020): Polychlorinated biphenyls in cow's milk, feed and soil in selected areas of Slovakia. Acta fytotechnica et zootechnica 23, 241-247

85. Tremolada P, Guazzoni N, Parolini M, Rossaro B, Bignazzi MM, Binelli A (2014): Predicting PCB concentrations in cow milk: validation of a fugacity model in high-mountain pasture conditions. Sci Total Environ 487, 471-80

86. V.Vanitha, G.Sarath Chandra, A.P.Nambi (2010): Polychlorinatedbiphenyls in milk and rumen liquor of stray cattle in chennai. Tamilnadu J. Veterinary \& Animal Sciences 6, 71-74

87. Van den Berg M, Birnbaum LS, Denison M, De Vito M, Farland W, Feeley M, Fiedler H, Hakansson H, Hanberg A, Haws L, Rose M, Safe S, Schrenk D, Tohyama C, Tritscher A, Tuomisto J, Tysklind M, Walker N, Peterson RE (2006): The 2005 World Health Organization reevaluation of human and Mammalian toxic equivalency factors for dioxins and dioxin-like compounds. Toxicol Sci 93, 223-41

88. Wang H-S, Sthiannopkao S, Du J, Chen Z-J, Kim K-W, Mohamed Yasin MS, Hashim JH, Wong CKC, Wong M-H (2011): Daily intake and human risk assessment of organochlorine pesticides (OCPs) based on Cambodian market basket data. J Hazard Mater 192, 1441-1449

89. Wang P, Shang H, Li H, Wang Y, Li Y, Zhang H, Zhang Q, Liang Y, Jiang G (2016): PBDEs, PCBs and PCDD/Fs in the sediments from seven major river basins in China: Occurrence, congener profile and spatial tendency. Chemosphere 144, 13-20 
90. Weber R, Herold C, Hollert H, Kamphues J, Ungemach L, Blepp M, Ballschmiter K (2018): Life cycle of PCBs and contamination of the environment and of food products from animal origin. Environ Sci Pollut Res Int 25, 16325-16343

91. Weber R, Bell L, Watson A, Petrlik J, Paun MC, Vijgen J (2019): Assessment of pops contaminated sites and the need for stringent soil standards for food safety for the protection of human health. Environ Pollut 249, 703-715

92. WHO (2000): Consultation on assessment of the health risk of dioxins; re-evaluation of the tolerable daily intake (TDI): Executive Summary. Food Addit Contam 17, 223-240

93. WHO (2010): Persistent Organic Pollutants: Impact on Child Health. World Health Organization

94. Wittsiepe J, Schrey P, Wilhelm M (2001): Dietary intake of PCDD/F by small children with different food consumption measured by the duplicate method. Chemosphere 43, 881-7

95. Zhang W, Sargis RM, Volden PA, Carmean CM, Sun XJ, Brady MJ (2012): PCB 126 and Other Dioxin-Like PCBs Specifically Suppress Hepatic PEPCK Expression via the Aryl Hydrocarbon Receptor. PloS one 7, e37103

\section{Tables}

Table 1: Descriptive Statistics (mean \pm Standard Deviation (SD), Range Values, Percentage (\%) and Detection Frequency (DF) of PCBs in Milk Samples of buffaloes and cows (ng g ${ }^{-1}$ ) 


\begin{tabular}{|c|c|c|c|c|c|c|c|c|c|c|c|c|}
\hline \multirow{2}{*}{$\begin{array}{c}\text { DL-PCBs } \\
\text { non-ortho substituted PCBs }\end{array}$} & \multicolumn{6}{|c|}{ Buffaloes $(n=26)$} & \multicolumn{6}{|c|}{ Cows $(n=28)$} \\
\hline & Mean & SD & $\min$ & $\max$ & $\%$ & $\mathrm{DF}$ & Mean & SD & $\min$ & $\max$ & $\%$ & DF \\
\hline РСВ 77 & 0.00 & 0.00 & 0.00 & 0.00 & 0.00 & 0.00 & 0.70 & 1.63 & 0.00 & 13.96 & 2.10 & 2.00 \\
\hline РCB 81 & 0.29 & 0.25 & 0.00 & 1.77 & 1.44 & 6.00 & 1.14 & 1.22 & 0.00 & 8.78 & 3.43 & 6.00 \\
\hline PCB 126 & 0.73 & 0.56 & 0.00 & 4.11 & 3.59 & 9.00 & 0.92 & 1.33 & 0.00 & 9.47 & 2.78 & 6.00 \\
\hline РCB 169 & 1.20 & 1.84 & 0.00 & 18.01 & 5.89 & 5.00 & 1.59 & 2.16 & 0.00 & 9.40 & 4.77 & 10.00 \\
\hline \multicolumn{13}{|l|}{ mono-ortho substituted PCBs } \\
\hline PCB 105 & 0.43 & 0.61 & 0.00 & 2.64 & 2.11 & 7.00 & 1.15 & 1.48 & 0.00 & 8.49 & 3.46 & 11.00 \\
\hline РCB 114 & 0.31 & 0.88 & 0.00 & 4.56 & 1.54 & 3.00 & 0.89 & 1.61 & 0.00 & 13.84 & 2.68 & 3.00 \\
\hline РCB 118 & 0.04 & 0.13 & 0.00 & 1.43 & 0.22 & 1.00 & 2.49 & 6.32 & 0.00 & 54.23 & 7.47 & 3.00 \\
\hline РCB 156 & 2.84 & 2.09 & 0.00 & 20.47 & 14.02 & 15.00 & 2.86 & 3.08 & 0.00 & 17.74 & 8.59 & 12.00 \\
\hline РCB 157 & 2.33 & 3.48 & 0.00 & 37.64 & 11.50 & 9.00 & 2.73 & 4.99 & 0.00 & 44.40 & 8.21 & 10.00 \\
\hline РCB 167 & 0.16 & 0.45 & 0.00 & 3.81 & 0.78 & 1.00 & 0.13 & 0.27 & 0.00 & 3.81 & 0.40 & 2.00 \\
\hline РCB 189 & 0.41 & 0.95 & 0.00 & 4.47 & 2.00 & 4.00 & 0.00 & 0.00 & 0.00 & 0.00 & 0.00 & 0.00 \\
\hline \multicolumn{13}{|l|}{ I-PCBs } \\
\hline РСВ 28 & 4.45 & 2.36 & 0.00 & 9.40 & 21.96 & 25.00 & 7.59 & 3.58 & 1.23 & 22.26 & 22.82 & 28.00 \\
\hline РCB 52 & 4.49 & 3.89 & 0.00 & 13.29 & 22.12 & 22.00 & 7.81 & 6.14 & 0.00 & 22.73 & 23.48 & 27.00 \\
\hline РCB 101 & 0.00 & 0.00 & 0.00 & 0.00 & 0.00 & 0.00 & 0.00 & 0.00 & 0.00 & 0.00 & 0.00 & 0.00 \\
\hline PCB 138 & 1.03 & 1.91 & 0.00 & 20.15 & 5.09 & 5.00 & 2.01 & 2.88 & 0.00 & 15.41 & 6.04 & 6.00 \\
\hline РCB 153 & 1.10 & 2.27 & 0.00 & 19.19 & 5.41 & 9.00 & 1.26 & 3.32 & 0.00 & 37.85 & 3.78 & 3.00 \\
\hline PCB 180 & 0.47 & 1.34 & 0.00 & 15.10 & 2.33 & 1.00 & 0.00 & 0.00 & 0.00 & 0.00 & 0.00 & 0.00 \\
\hline$\sum$ DL-PCBs & 8.74 & & & & & & 14.60 & & & & & \\
\hline Mean of $\sum$ DL-PCBs & 0.79 & & 0.00 & 2.84 & & & 1.33 & & 0.00 & 2.86 & & \\
\hline$\sum \mathrm{I}-\mathrm{PCBs}$ & 11.54 & & & & & & 18.68 & & & & & \\
\hline Mean of $\sum$ I-PCBs & 1.92 & & 0.00 & 4.49 & & & 3.11 & & 0.00 & 7.81 & & \\
\hline$\sum$ PCBs & 20.28 & & & & & & 33.28 & & & & & \\
\hline
\end{tabular}

Table 2: TEQ values for dioxin - like PCBs (DL-PCBs) (ng TEQ g ${ }^{-1}$ ) in milk samples of buffaloes and cows

\begin{tabular}{cccccc}
\hline & & \multicolumn{2}{c}{ Buffaloes } & \multicolumn{2}{c}{ Cows } \\
\cline { 3 - 6 } DL-PCBs & TEF (2005) & mean & TEQ & mean & TEQ \\
\hline PCB 77 & 0.0001 & 0.00 & 0 & 0.70 & $6.99354 \mathrm{E}-05$ \\
PCB 81 & 0.0003 & 0.29 & $8.75 \mathrm{E}-05$ & 1.14 & 0.000342439 \\
PCB 126 & 0.1 & 0.73 & 0.072727 & 0.92 & 0.092482168 \\
PCB 169 & 0.03 & 1.20 & 0.035859 & 1.59 & 0.047621126 \\
PCB 105 & 0.00003 & 0.43 & $1.28 \mathrm{E}-05$ & 1.15 & $3.45763 \mathrm{E}-05$ \\
PCB 114 & 0.00003 & 0.31 & $9.35 \mathrm{E}-06$ & 0.89 & $2.67133 \mathrm{E}-05$ \\
PCB 118 & 0.00003 & 0.04 & $1.34 \mathrm{E}-06$ & 2.49 & $7.4557 \mathrm{E}-05$ \\
PCB 156 & 0.00003 & 2.84 & $8.53 \mathrm{E}-05$ & 2.86 & $8.57733 \mathrm{E}-05$ \\
PCB 157 & 0.00003 & 2.33 & $7 \mathrm{E}-05$ & 2.73 & $8.19604 \mathrm{E}-05$ \\
PCB 167 & 0.00003 & 0.16 & $4.76 \mathrm{E}-06$ & 0.13 & $3.94991 \mathrm{E}-06$ \\
PCB 189 & 0.00003 & 0.41 & $1.22 \mathrm{E}-05$ & 0.00 & 0.00 \\
sum & & 8.74 & 0.11 & 14.60 & 0.14 \\
mean & & 0.79 & 0.01 & 1.33 & 0.01 \\
min & & 0.00 & 0.00 & 0.00 & 0.00 \\
max & & 2.84 & 0.07 & 2.86 & 0.09 \\
$*$ (Van den Berg et al. 2006) & & & & & \\
\hline
\end{tabular}


Table 3: EDI (ng Kg ${ }^{-1} \mathrm{~d}^{-1}$ ) for dioxin like PCBs (DL-PCBs) and indicator PCBs (I-PCBs) in milk samples of buffaloes and cows

\begin{tabular}{cccccc}
\hline & \multicolumn{2}{c}{ Buffaloes } & \multicolumn{2}{c}{ Cows } & Standard \\
\cline { 2 - 6 } DL-PCBs & adults & children & adults & children & \\
\hline PCB 77 & 0.0000 & 0.0000 & 0.0007 & 0.0015 & $5.5 \mathrm{ng} \mathrm{Kg}^{-1}$ \\
PCB 81 & 0.0009 & 0.0019 & 0.0034 & 0.0074 & \\
PCB 126 & 0.7273 & 1.5753 & 0.9248 & 2.0032 & \\
PCB 169 & 0.3586 & 0.7767 & 0.4762 & 1.0315 & \\
PCB 105 & 0.0001 & 0.0003 & 0.0003 & 0.0007 & \\
PCB 114 & 0.0001 & 0.0002 & 0.0003 & 0.0006 & \\
PCB 118 & 0.0000 & 0.0000 & 0.0007 & 0.0016 & \\
PCB 156 & 0.0009 & 0.0018 & 0.0009 & 0.0019 & \\
PCB 157 & 0.0007 & 0.0015 & 0.0008 & 0.0018 & \\
PCB 167 & 0.0000 & 0.0001 & 0.0000 & 0.0001 & \\
PCB 189 & 0.0001 & 0.0003 & 0.0000 & 0.0000 & \\
I-PCBs & & & & & $40000 \mathrm{ng} \mathrm{Kg}^{-1}$ \\
PCB 28 & 44.53 & 96.45 & 75.94 & 164.49 & \\
PCB 52 & 44.86 & 97.17 & 78.14 & 169.26 & \\
PCB 101 & 0.00 & 0.00 & 0.00 & 0.00 & \\
PCB 138 & 10.32 & 22.36 & 20.10 & 43.54 & \\
PCB 153 & 10.97 & 23.77 & 12.58 & 27.26 & \\
PCB 180 & 4.72 & 10.22 & 0.00 & 0.00 & \\
\hline
\end{tabular}

Table 4: Hazard Ratio for carcinogenic risk

\begin{tabular}{lcccc}
\hline & \multicolumn{2}{c}{ Buffaloes } & \multicolumn{2}{c}{ Cows } \\
\cline { 2 - 5 } DL-PCBs & 0.01 & 0.03 & 0.01 & 0.04 \\
$\sum$ PCBs & 0.58 & 2.73 & 0.94 & 4.42 \\
\hline
\end{tabular}

References:

Van den Berg M et al. (2006) The 2005 World Health Organization reevaluation of human and Mammalian toxic equivalency factors for dioxins and dioxin-like compounds Toxicol Sci 93:223-241 doi:10.1093/toxsci/kfl055

\section{Figures}


(a)

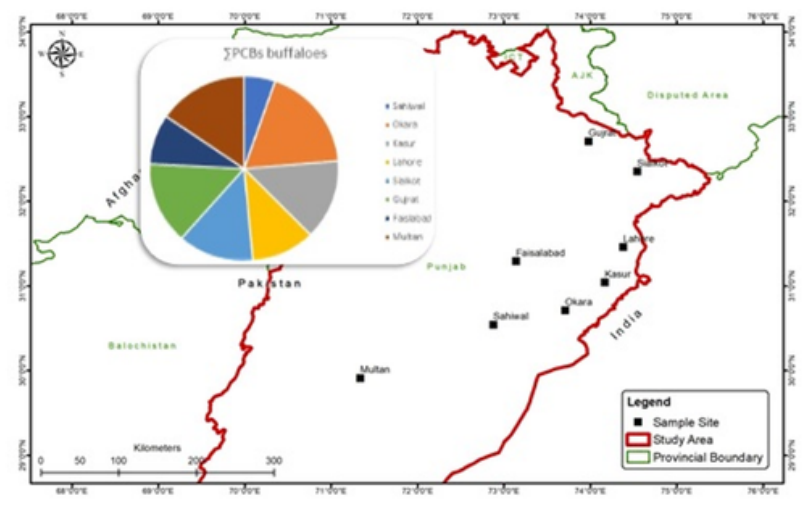

(b)

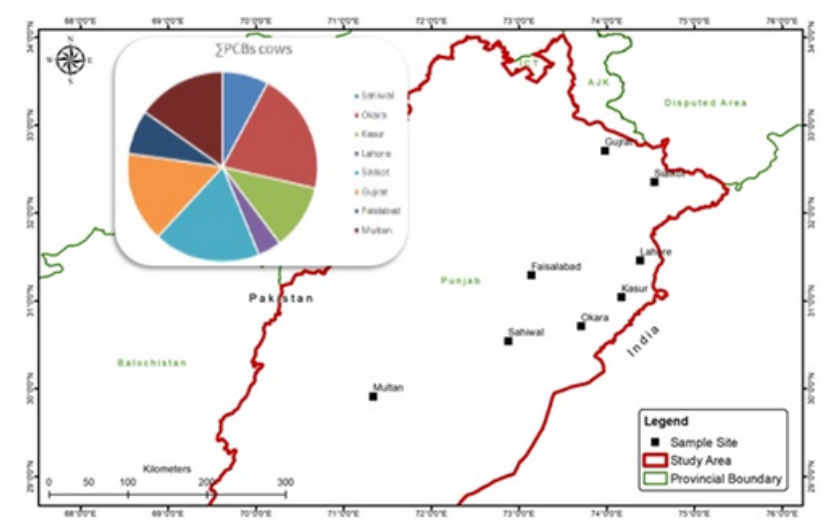

\section{Figure 1}

Spatial distribution of (a) $\sum$ PCBs-Buffaloes and (b) Cows

(a)

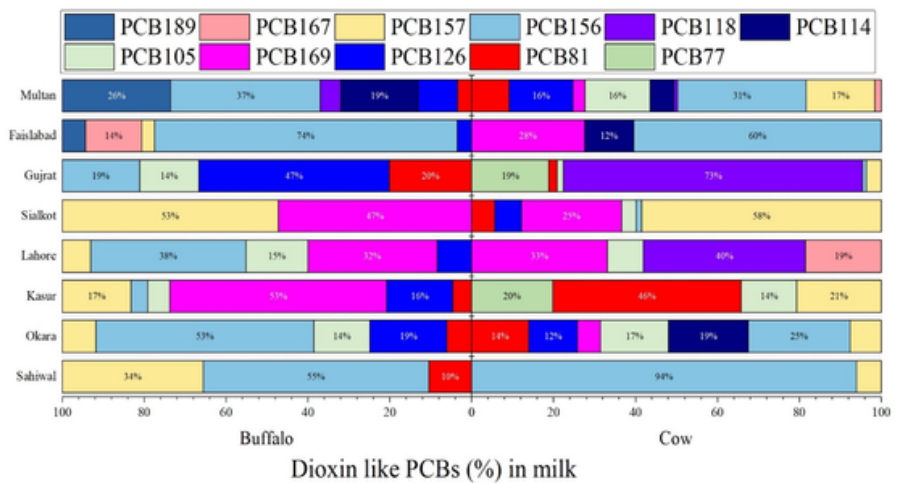

(b)

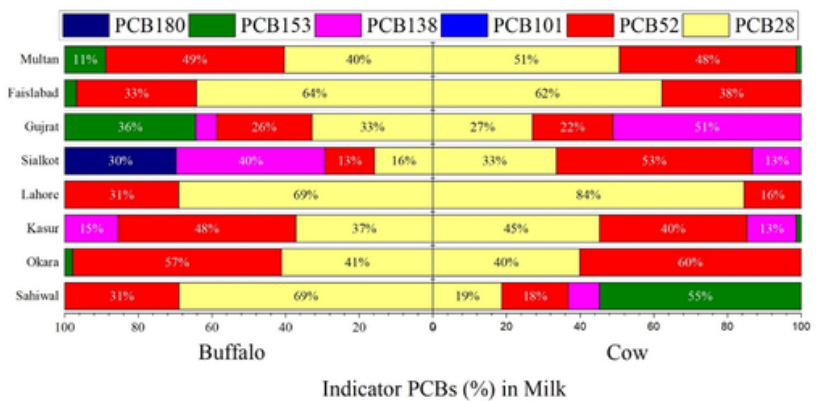

Figure 2

Spatial distribution of (a). DL-PCBs (\%) and (b). I-PCBs (\%) in buffaloes and cows

\section{Supplementary Files}

This is a list of supplementary files associated with this preprint. Click to download.

- supportingmaterialPCBSaman.docx 